\title{
Questes
}

Revue pluridisciplinaire d'études médiévales

$4 \mid 2003$

L'arbre

\section{Carla Casagrande, Silvana Vecchio, Histoire des Péchés Capitaux au Moyen Âge, Paris, Aubier, 2002 (coll. Historique)}

Pierre Levron

\section{OpenEdition}

Journals

Édition électronique

URL : http://journals.openedition.org/questes/1764

DOI : 10.4000/questes.1764

ISSN : 2109-9472

Éditeur

Les Amis de Questes

Édition imprimée

Date de publication : 15 mai 2003

Pagination : $27-28$

ISSN : 2102-7188

Référence électronique

Pierre Levron, «Carla Casagrande, Silvana Vecchio, Histoire des Péchés Capitaux au Moyen Âge, Paris, Aubier, 2002 (coll. Historique)», Questes [En ligne], 4| 2003, mis en ligne le 01 janvier 2014, consulté le 25 septembre 2020. URL : http://journals.openedition.org/questes/1764 ; DOI : https://doi.org/ 10.4000/questes. 1764

Ce document a été généré automatiquement le 25 septembre 2020.

(c) Association des amis de « Questes » 
Carla Casagrande, Silvana Vecchio, Histoire des Péchés Capitaux au Moyen Âge, Paris, Aubier, 2002 (coll. Historique)

Pierre Levron

\section{RÉFÉRENCE}

Carla Casagrande et Silvana Vecchio, Histoire des Péchés Capitaux au Moyen Âge, Paris, Aubier, coll. historique, 2002

\section{NOTE DE L'ÉDITEUR}

Cet article n'a pas encore fait l'objet d'une autorisation de publication. 